\title{
Penerapan Algoritma FP-GROWTH untuk Menemukan Pola Peminjaman Buku Perpustakaan UIN Raden Fatah Palembang
}

\author{
Muhamad Kadafi
}

\begin{abstract}
Abstrak--Proses pengolahan data transaksi peminjaman buku Perpustakaan UIN Raden Fatah Palembang sudah menggunakan Sistem Informasi Perpustakaan, tetapi data buku yang ada belum di manfaatkan untuk analisa guna pengambilan keputusan di perpustakaan. Salah satunya adalah dengan cara penggalian informasi atau pola yang penting dan menarik dari jumlah data besar yang disebut data mining. Hal terpenting dalam teknik mining adalah aturan untuk menemukan pola frekuensi tinggi antara himpunan itemset yang disebut dengan association rule (aturan assosiasi). Tujuan dari penelitian ini adalah menemukan pola peminjaman buku dengan menggunakan algoritma FP-Growth. Hasil dari penelitian ini adalah pembandingan pola yang terbentuk dengan memasukan nilai support dan conffident yang berbeda pada data transaksi yg sama. Alat yang digunakan untuk membantu proses pengolahan data yaitu rapid miner studio versi 9.0. Pola yang terbentuk bisa digunakan sebagai salah satu referensi untuk pengambilan keputusan.
\end{abstract}

Kata Kunci-Association Rule, Data Mining, FPGROWTH, Perpustakaan.

\section{PENDAHULUAN}

Universitas Islam Negeri (UIN) Raden Fatah Pelembang adalah salah satu peguruan tinggi negeri di kota Palembang Sumatera Selatan. UIN Raden Fatah Pelembang dilengkapi dengan berbagai fasilitas untuk menunjang kegiatan akademik, dimana salah satunya adalah fasilitas berupa perpustakaan. Perpustakaan UIN Raden Fatah Palembang memiliki koleksi buku yang cukup banyak dari berbagai cabang ilmu pengetahuan.

Proses Pengolahan Data transaksi peminjaman dan pengembalian buku pada Perpustakaan UIN Raden sudah menggunakan Sistem Informasi Perpustakaan. Sistem Informasi Perpustakaan UIN Raden Fatah dapat menangani Transaksi peminjaman dan pengembalian buku yang banyak, tetapi data transaksi buku yang ada belum dimanfaatkan untuk analisa guna pengambilan keputusan di perpustaakan UIN Raden Fatah Palembang, contohnya adalah memberi informasi pada pengunjungnya tentang buku-buku yang berelasi, menjaga ketersedian stok buku - buku yang berelasi agar berimbang, pengaturan peletakan buku-buku yang

Muhamad Kadafi, Sistem Informasi, UIN Raden Fatah Palembang, Indonesia (email kadafi_uin@radenfatah.ac..id) berelasi pada rak-rak buku, dan banyak putusan strategis lain yang bermanfaat.[1]

Para pengambil keputusan bisa memanfaatkan gudang data yang sudah dimiliki untuk melakukan analisa dalam mengambil keputusan, salah satunya yaitu dengan cara penggalian informasi atau pola yang penting dan menarik dari data jumlah besar, yang disebut dengan data mining. Data mining diartikan sebagai menambang data atau upaya untuk menggali informasi yang berharga dan berguna pada database yang sangat besar. Hal terpenting dalam teknik data mining adalah aturan untuk menemukan pola frekuensi tinggi antara himpunan itemset yang disebut dengan Association Rule (Aturan Asosiasi).

Salah satu teknik yang digunakan untuk menentukan pola tersebut yaitu dengan menggunakan algoritma frequent Pattern-Growth (FP-Growth). Algoritma ini adalah bagian dari teknik asosiasi pada data mining. Adapun FP-Growth sendiri adalah salah satu altenatif algoritma yang dapat digunakan untuk menentukan himpunan data yang paling sering mucul (frequent itemset) dalam sekumpulan data. Karakteristik algoritma FP-Growth adalah struktur data yang digunakan dalam tree yang disebut FP-Tree. Dengan menggunakan FP-Tree, algoritma FP-Growth dapat langsung mengekstrak frequent itemset dari FP-Tree[2].

\section{TINJAUAN PUSTAKA}

\section{A. Data Mining}

Data mining disebut sebagai suatu proses untuk menemukan hubungan yang berarti pola dan kecenderungan dengan memeriksa dalam sekumpulan data besar yang tersimpan dalam penyimpanan dengan menggunakan teknik pengenalan pola seperti teknik statistik dan matematika (Larose, 2005).

Pengelompokkan data mining dijadikan sebagai teknik dari data mining berdasarkan tugas yang bisa dilakukan, yaitu [3]:

a. Deskripsi

Para penulis biasanya mencoba menemukan cara untuk mendeskripsikan pola dan trend yang tersembunyi dalam data. Sebagai contoh, petugas pengumpulan suara mungkin tidak dapat menentukan keterangan atau fakta bahwa siapa yang tidak cukup profesional akan sedikit didukukng dalam pemilihan presiden. Deskripsi 
dari pola dan kecendrungan sering memberikan kemungkinan penjelasan untuk suatu pola atau kecendrungan

b. Estimasi

Estimasi mirip dengan klasifikasi, kecuali variabel tujuan yang lebih ke arah numerik daripada kategori. Misalnya, akan dilakukan estimasitekanan systolic dari pasien rumah sakit berdasarkan umur pasien, jenis kelamin, indeks berat badan, dan level sodium darah. Metode data mining yang terdapat di dalam estimasi yaitu, ( Linear Regression, Neural Network, Support Vector)

c. Prediksi

Prediksi memiliki kemiripan dengan estimasi dan klasifikasi. Hanya saja, prediksi hasilnya menunjukkan sesuatu yang belum terjadi (mungkin terjadi dimasa depan). Misalnya, ingin diketahui prediksi harga beras tiga bulan yang akan datang. Metode data mining yang terdapat di dalam prediksi yaitu, (Linear Regression, Neural Network, Support Vector).

d. Klasifikasi

Dalam klasifikasi variabel, tujuan bersifat kategorik. Misalnya, mengklasifikasikan pendapatan dalam tiga kelas, yaitu pendapatan tinggi, pendapatan sedang, dan pendapatan rendah. Metode data mining yang terdapat di dalam klasifikasi yaitu, (Naive Bayes, K-Nearest, C4.5, ID3, CART, Linear Discriminant Analysis, Logistic Regression ).

e. Clustering

Clustering lebih kearah pengelompokan record, pengamatan, atau kasus dalam kelas yang memiliki kemiripan. Sebuah cluster adalah kumpulan record yang memiliki kemiripan satu dengan yang lain dan memiliki ketidak miripan dengan recordrecord dalam cluster yang lain, misalnya untuk tujuan audit akuntasi akan dilakukan segmentasi perilaku financial dalam kategori dan mencurigakan. Metode data mining yang terdapat di dalam clustering yaitu, (K-Means, K-Medolds, Self-Organizing Map (SOM), Fuzzy C-Means).

f. Asosiasi

Mengidentifikasi hubungan antara berbagai peristiwa yang terjadi pada satu waktu. Pendekatan asosiasi tersebut menekankan sebuah kelas masalah yang dicirikan dengan analisis keranjang pasar. Metode data mining yang terdapat di dalam asosiasi yaitu, (FP-Growth, A Priori, Coefficient of Correlation, Chi Square).

\section{B. Knowledge Discovery In Database}

Knowledge Discovery in Database (KDD) adalah proses menentukan informasi yang berguna serta pola-pola yang ada dalam data. Informasi ini terkandung dalam basis data yang berukuran besar yang sebelumnya tidak diketahui dan potensial bermanfaat. Data Mining merupakan salah satu langkah dari serangkaian proses iterative KDD [3].

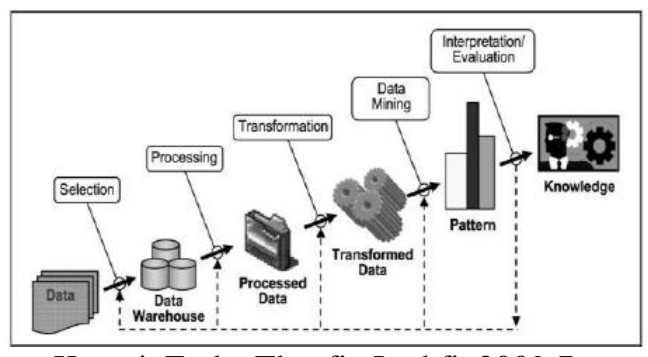

Sumber: Kursni, Emha Thaufiq Luthfi, 2009:7

Gambar 1 Tahapan Dalam KDD

Tahapan proses KDD terdiri dari:

a. Data Selection

Pada proses ini dilakukan pemilihan himpunan data, menciptakan himpunan data target, atau memfokuskan pada subset variable (sampel data) dimana penemuan (discovery) akan dilakukan. Hasil seleksi disimpan dalam suatu berkas yang terpisah dari basis data operasional.

b. Pre-Processing dan Cleaning Data

Pre-Processing dan Cleaning Data dilakukan membuang data yang tidak konsisten dan noise, duplikasi data, memperbaiki kesalahan data, dan bisa diperkaya dengan data eksternal yang relevan.

c. Transformation

Proses ini mentransformasikan atau menggabungkan data ke dalam yang lebih tepat untuk melakukan proses mining dengan cara melakukan peringkasan (agregasi).

d. Data Mining

Proses Data Mining yaitu proses mencari pola atau informasi menarik dalam data terpilih dengan menggunakan teknik, metode atau algoritma tertentu sesuai dengan tujuan dari proses KDD secara keseluruhan.

e. Interpretation / Evaluasi

Proses untuk menerjemahkan pola-pola yang dihasilkan dari Data Mining. Mengevaluasi (menguji) apakah pola atau informasi yang ditemukan bersesuaian atau bertentangan dengan fakta atau hipotesa sebelumnya. Pengetahuan yang diperoleh dari pola-pola yang terbentuk dipresentasikan dalam bentuk visualisasi.

\section{Association Rule}

Association rule merupakan salah satu metode yang bertujuan mencari pola yang sering muncul di antara banyak transaksi, dimana setiap transaksi terdiri dari beberapa item sehingga metode ini akan mendukung sistem rekomendasi melalui penemuan pola antar item dalam transaksi-transaksi yang terjadi.

Metodologi dasar analisis asosiasi terbagi menjadi dua tahap:

1. Analisa pola frekuensi tinggi

Tahap ini mencari kombinasi item yang memenuhi syarat minimum dari nilai support dalam database. Nilai support sebuah item diperoleh dengan rumus berikut:

Support $(\mathrm{A})=\frac{\text { Jumlah Transaksi Mengandung A }}{\text { Total Transaksi }}$ 
Sedangkan nilai support dari 2 item diperoleh dari rumus berikut.

$$
\begin{aligned}
& \text { Support (A, B) } \\
& =\frac{\sum \text { Transakasi Mengandung Adan B }}{\sum \text { Transaksi }}
\end{aligned}
$$

\section{Pembentukan aturan assosiatif}

Setelah semua pola frekuensi tinggi ditemukan, barulah dicari aturan asosiasi yang memenuhi syarat minimum untuk confidence dengan menghitung confidence aturan asosiatif A U B. Nilai confidence dari aturan A U B diperoleh dengan rumus berikut.

$$
\begin{aligned}
& \text { Confidence } \mathrm{P}(\mathrm{B} \mid \mathrm{A}) \\
& =\frac{\sum \text { Transakasi Mengandung A dan } B}{\sum \text { Transaksi Mengandung } A}
\end{aligned}
$$

\section{FP-GROWTH}

FP_Growth adalah algoritma untuk menemukan frequent itemset tanpa melalui proses penggenerasian kandidat seperti pada algoritma apriori. Algoritma FP growth merupakan pengembangan dari algoritma apriori yang mengadopsi prinsip divide-and-conquer yaitu dengan cara mengkompresi database dan merepresentasikan frequent itemset ke dalam bentuk Frequent Pattern Tree (FP-Tree) yang menyimpan informasi assosiasi antar itemset. Kemudian membagi database terkompresi tersebut ke dalam suatu set conditional database dimana pada masing - masing setnya berasosiasi dengan satu frequent item atau "pattern fragment" dan menambang setiap database secara terpisah. Pada setiap "pattern fragment", hanya dataset yang berasosiasi saja yang di perlu di tambang. Adapun Langkah - Langkah dari Algoritma FP-Growth adalah sebagai berikut [4]:

1. Scan database dengan cara yang sama seperti algoritma apriori.

2. Langkah berikutnya adalah pembentukan FP-Tree. FP Tree dibuat dengan cara berikut :

a. Pertama, Buat Root dari Tree dan di label dengan "null"

b. Item pada setiap transaksi di proses dalam bentuk list order (Diurutkan berdasarkan Descending Support count), selanjutnya adalah pembentukan simpul untuk setiap transaksi. Nilai support count akan bertambah 1 jika ada node yang sama dalam dalam suatu prefix. Untuk node yang bersesuaian akan saling terhubung (linked).

3. Selanjutnya adalah Menambang FP-Tree dengan cara sebagai berikut :

a. Membentuk conditional Pattern Base ("sub database" yang terdiri dari suatu set prefix path di dalam FP-Tree yang terbentuk bersama dengan suffix pattern).

b. Membentuk Conditional FP-Tree

c. Frequently Pattern Growth di dapat dari penggabungan antara suffix pattern dengan Frequently Pattern yang dihasilkan dari Conditional FP-Tree.

\section{METODOLOGI PENELITIAN}

Metode penelitian yang digunakan dalam penelitian ini adalah pendekatan kualitatif. Metode penelitian kualitatif adalah metode penelitian yang berlandaskan pada filsafat postpositivisme, digunakan untuk meneliti pada obyek yang alamiah (sebagai awalnya sebagai eksperimen) dimana peneliti sebagai instrumen kunci, teknik pengumpulan data dilakukan secara triangulasi (gabungan), analisa bersifat indukti/kualitatif dan hasil penelitian kualitatif lebih menekankan pada generalisasi [5].

\section{HASIL}

\section{A. Pengolahan Data Mining}

Adapun tahapan yang digunakan dalam pengolahan data mining pada penelitian ini, yaitu mengikuti tahapan Knowledge Discovery in Database (KDD). Adalah sebagai berikut :

1. Data Selection

Data yang digunakan adalah data transaksi peminjaman buku tahun 2017. Transaksi Data peminjaman buku pada tahun 2017 ada sebanyak 3047 Buah transaksi. Atribut yang nanti akan digunakan untuk proses pengolahan data mining. Yaitu :

a. Tanggal Pinjam.

Tanggal pinjam merupakan attribut yang berisi informasi waktu terjadinya transaksi peminjaman buku.

b. Jenis Buku

Klasifikasi adalah attribut yang berisi informasi kode jenis buku, penggolongan buku berdasarkan jenis buku. Berikut ini adalah pengolongan buku berdasarkan jenis buku yaitu :

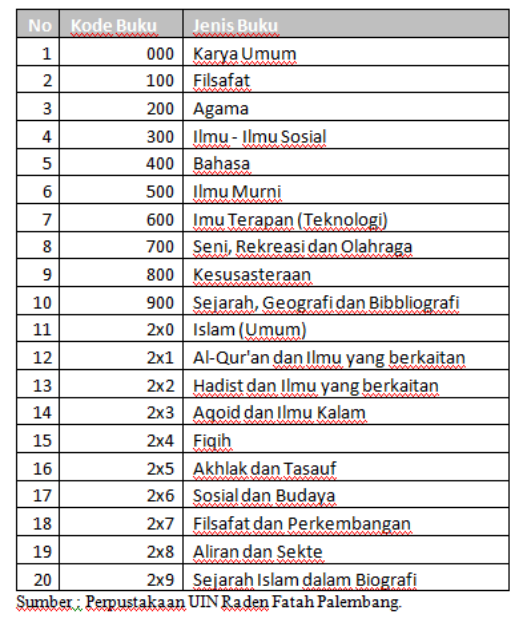

Gambar 2. Penggolongan Jenis Buku

2. Preprocessing

Pada tahapan ini preprocessing ini akan dilakukan proses integrasi data untuk menghubungkan tabel data peminjaman, selanjutnya dilakukan data cleaning untuk menghasilkan dataset yang bersih sehingga dapat digunakan dalam tahap berikutnya yaitu mining. 
a. Integrasi Data

Tahap ini adalah proses penggabungan data dari berbagai database yang berbeda, sehingga data tersebut saling berintegrasi. Data integrasi dilakukan pada atributatribut yang mengidentifikasiskan entitasentitas yang unik. Pada tahapan ini tidak ada penggabungan data dikarenakan data yang diambil berasal dari satu database.

b. Data Cleaning

Pada tahapan ini data yang tidak relevan, missing value, dan redudant harus dibersihkan. Hal ini dikarenakan data yang ralevan, tidak missing value, dan tidak redudant merupakan syarat awal dalam melakukan data mining. Suatu data dikatakan missing value jika terdapat atribut dalam dataset yang tidak berisi nilai atau kosong, sedangkan data dikatakan redudant jika dalam satu dataset lebih dari satu record yang berisi nilai yang sama, setelah melakukan cleaning terhadap data yang lebih memenuhi syarat berdasarkan data peminjaman.

3. Transformation

Tahap Transformation merupakan tahapan merubah data kedalam bentuk yang sesuai untuk selanjutnya di proses dalam pengolahan data mining. Berikut adalah contoh tabel sebagian transformasi data transaksi peminjaman buku 2017.

\begin{tabular}{|r|r|l|}
\hline No & Tandeal Transaksi & \multicolumn{1}{|c|}{ Item Peminiaman } \\
\hline 1 & $1 / 19 / 2017$ & $000,400,300,600$ \\
\hline 2 & $3 / 9 / 2017$ & $300,2 \times 9,2 \times 7,2 \times 6,000$ \\
\hline 3 & $3 / 14 / 2017$ & $2 \times 5,2 \times 3,400,2 \times 2,300,2 \times 9,900,2 \times 4,800$ \\
\hline 4 & $3 / 20 / 2017$ & $300,2 \times 1,2 \times 4,800,600,900,2 \times 2$ \\
\hline 5 & $3 / 21 / 2017$ & $300,2 \times 1,100,800,200,2 \times 5,000$ \\
\hline 6 & $3 / 22 / 2017$ & $000,2 \times 4,100,500,700,900,2 \times 0,200,400$ \\
\hline 7 & $3 / 24 / 2017$ & $000,300,700,900,100$ \\
\hline 8 & $3 / 27 / 2017$ & $100,2 \times 0,2 \times 1,400,500,2 \times 7$ \\
\hline 9 & $3 / 29 / 2017$ & $300,000,800,2 \times 1,2 \times 3,200$ \\
\hline 10 & $3 / 30 / 2017$ & $200,400,500,2 \times 9,2 \times 0,2 \times 6,000,600$ \\
\hline 11 & $3 / 31 / 2017$ & $600,400,100,2 \times 2,300$ \\
\hline 12 & $4 / 3 / 2017$ & $300,2 \times 3,2 \times 5,900,000,200,2 \times 7$ \\
\hline 13 & $4 / 5 / 2017$ & $2 \times 9,2 \times 2,2 \times 0,000,400,200,300$ \\
\hline 14 & $4 / 11 / 2017$ & $2 \times 2,2 \times 6,600,2 \times 1,300$ \\
\hline 15 & $4 / 12 / 2017$ & $300,2 \times 1,2 \times 7,2 \times 0,800,2 \times 2$ \\
\hline 16 & $4 / 13 / 2017$ & $800,400,300,2 \times 9,100$ \\
\hline 17 & $4 / 17 / 2017$ & $100,300,2 \times 6,2 \times 0,600$ \\
\hline 18 & $4 / 27 / 2017$ & $2 \times 9,300,2 \times 2,200,600$ \\
\hline 19 & $5 / 2 / 2017$ & $2 \times 4,500,400,300,000$ \\
\hline
\end{tabular}

Gambar 3. Data Buku yang sudah di transformasi

4. Data Mining

Tahapan data mining merupakan proses untuk mencari pola atau informasi yang menarik dalam data terpilih. Metode yang digunakan adalah Association Rule dengan Algoritma FP_GROWTH. Tahapan Algoritma FPGROWTH adalah sebagai berikut :

a. Menentukan data transaksi peminjaman buku, penulis menggunakan 12 transaksi yang di ambil secara random.

\begin{tabular}{|r|r|l|}
\hline No & Tandial transaksi & \multicolumn{1}{|c|}{ Item Peminiaman } \\
\hline 1 & $1 / 19 / 2017$ & $000,400,300,600$ \\
\hline 2 & $3 / 29 / 2017$ & $300,000,800,2 \times 1,2 \times 3,200$ \\
\hline 3 & $3 / 24 / 2017$ & $000,300,700,900,100$ \\
\hline 4 & $4 / 12 / 2017$ & $300,2 \times 1,2 \times 7,2 \times 0,800,2 \times 2$ \\
\hline 5 & $4 / 17 / 2017$ & $100,300,2 \times 6,2 \times 0,600$ \\
\hline 6 & $5 / 8 / 2017$ & $2 \times 6,2 \times 7,200,2 \times 4,300$ \\
\hline 7 & $9 / 15 / 2017$ & $2 \times 6,100,900,2 \times 0,2 \times 8,2 \times 9$ \\
\hline 8 & $10 / 9 / 2017$ & $000,200,2 \times 1,600,300$ \\
\hline 9 & $11 / 1 / 2017$ & $300,000,200,2 \times 6,2 \times 0$ \\
\hline 10 & $11 / 27 / 2017$ & $2 \times 3,300,2 \times 6,100,800$ \\
\hline 11 & $12 / 11 / 2017$ & $000,800,2 \times 3,2 \times 7,300$ \\
\hline 12 & $12 / 13 / 2017$ & $300,2 \times 2,900,600,2 \times 0,2 \times 1$ \\
\hline
\end{tabular}

Gambar 4. Transaksi Peminjaman Buku

Selanjutnya menghitung jumlah frekuensi item set dan menghitung nilai support.

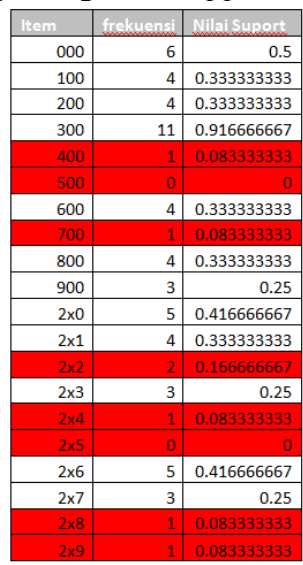

\section{Gambar 5. Perhitungan Frekuensi dan Nilai} Support Setiap itemset

Kemudian mengurutkan item berdasarkan prioritas dilihat dari Nilai frekuensi yang paling besar, dan menghilangkan item yang tidak memenuhi minimal support, minimal support item yang digunakan adalah $\geq 0.2$

\begin{tabular}{|r|r|l|}
\hline No & Tanimal Transaksi & \multicolumn{1}{|c|}{ Item Peminiaman } \\
\hline 1 & $1 / 19 / 2017$ & $300,000,600$ \\
\hline 2 & $3 / 29 / 2017$ & $300,000,200,800,2 \times 1,2 \times 3$ \\
\hline 3 & $3 / 24 / 2017$ & $300,000,100,900$ \\
\hline 4 & $4 / 12 / 2017$ & $300,2 \times 0,800,2 \times 1,2 \times 7$ \\
\hline 5 & $4 / 17 / 2017$ & $300,2 \times 0,2 \times 6,100,600$ \\
\hline 6 & $5 / 8 / 2017$ & $300,2 \times 6,200,2 \times 7$ \\
\hline 7 & $9 / 15 / 2017$ & $2 \times 0,2 \times 6,100,900$ \\
\hline 8 & $10 / 9 / 2017$ & $300,000,200,600,2 \times 1$ \\
\hline 9 & $11 / 1 / 2017$ & $300,000,2 \times 0,2 \times 6,200$ \\
\hline 10 & $11 / 27 / 2017$ & $300,2 \times 6,100,800,2 \times 3$ \\
\hline 11 & $12 / 11 / 2017$ & $300,000,800,2 \times 3,2 \times 7$ \\
\hline 12 & $12 / 13 / 2017$ & $300,2 \times 0,600,2 \times 1,900$ \\
\hline
\end{tabular}

Gambar 6. Transaksi Peminjaman yang sudah di urut

b. Selanjutnya adalah pembentukan FP Tree berdasarkan Transaksi peminjaman buku yang telah diurutkan dari Gambar 6.

FP-Tree dibangun dengan membaca data set satu transaksi dalam satu waktu dan memetakannya ke dalam path pada FP-Tree. 


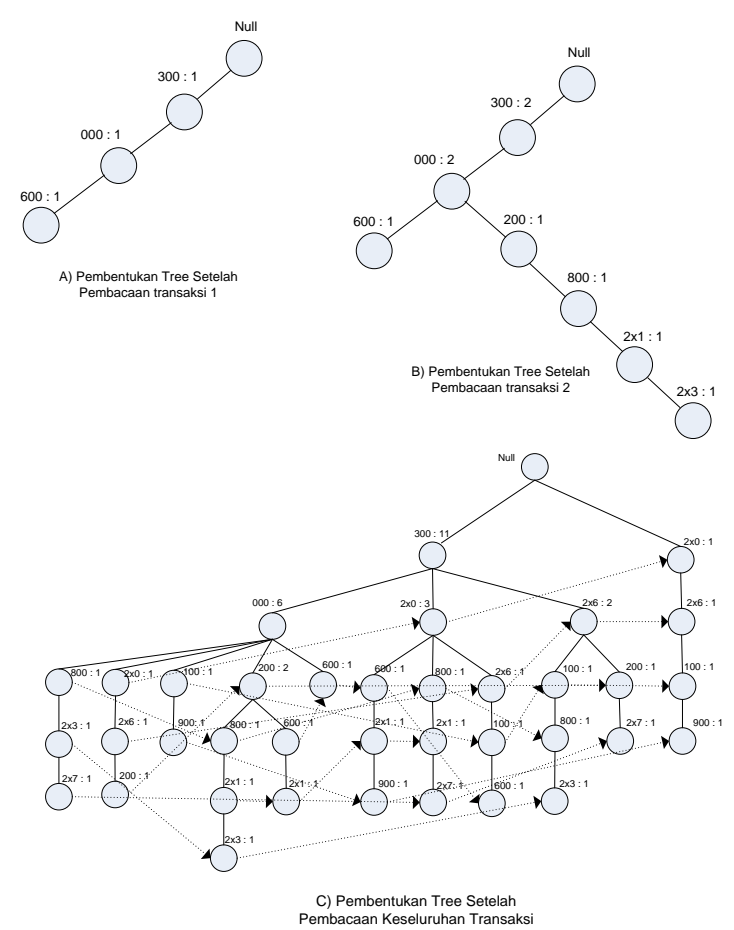

Gambar 7. Proses Pembentukan Tree

Pada Gambar 7. FP-Tree terdiri dari node root yang direpresentasikan dengan symbol null, setelah itu FP-Tree ditambahkan dengan cara sebagai berikut :

a.) Setelah Pembacaan Transaksi pertama $\{300,000,600\}$, Sebuah path kemudian di bentuk dari null $\rightarrow 300 \rightarrow 000 \rightarrow 600$, dan setiap node masing masing di label dengan nama 300, 000, 600, dan setiap node memiliki nilai support count $=1$.

b.) Setelah Pembacaan transaksi kedua $\{300$, $000,200,800,2 \times 1,2 \times 3\}$, pembentukan path di mulai dari null $\rightarrow 300 \rightarrow 000 \rightarrow$ $200 \rightarrow 800 \rightarrow 2 \times 1 \rightarrow 2 \times 3$, node baru terbentuk dan di label dengan nama 200, $800,2 \times 1,2 \times 3$, dan memiliki nilai support count $=1$. Sedangkan untuk transaksi 300 , 000 karna melewati lintasan node 300 dan 000, yang sudah terbentuk sebelumnya maka nilai support count bertambah menjadi 2.

c.) Kemudian proses seperti di atas berlanjut sampai semua pembacaan transaksi dipetakan dalam satu path pada FP-Tree.

c. Pembentukan Conditional Patern Base yang terdiri dari prefix path yang terkandung akhiran item tertentu. Misalnya untuk prefix path berakhiran $2 \times 3$ seperti gambar 8 .

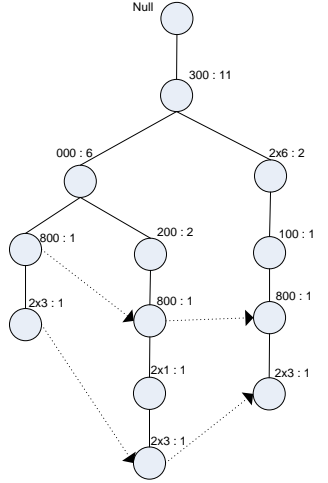

Gambar 8. Prefix path yang mengandung node berakhiran $2 \times 3$

Prefix path yang mengandung akhiran item $2 \times 3$ di ambil dari FP-Tree yang sudah terbentuk sebelumnya. Dari prefix path tersebut di buat Conditional Pattern Base seperti pada tabel 1. di bawah ini :

Tabel 1. Conditional Pattern Base untuk path yang mengandung $2 \times 3$

\begin{tabular}{|l|l|}
\hline Suffix & Conditional Pattern Base \\
\hline $2 \times 3$ & $\begin{array}{l}\{300,000,800: 1\}\{300,000,200,800,2 \times 1: 1\}\{300,2 \times 6,100, \\
800: 1\}\end{array}$ \\
\hline
\end{tabular}

Dari Conditional Pattern Base Sebelumnya selanjutnya adalah membuat Conditional FPTree yang mengandung node berakhiran $2 \times 3$

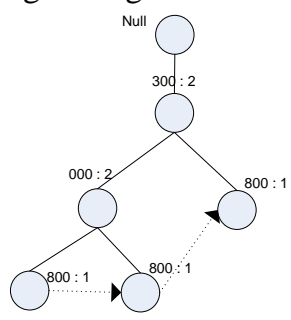

\section{Gambar 9 Conditional FP-Tree untuk Path yang mengandung node $2 \times 3$}

Pada gambar 9. Conditional FP-Tree dibentuk dengan menghitung ulang nilai support count. Karena ada beberapa nilai dari support count terdiri dari transaksi yang tidak mengandung item $2 \times 3$. Dan menghilangkan node $2 \times 3$, karena support count pada prefix path yang sudah di update hanya mencerminkan transaksi yang mengandung item 2x3. Kemudian menghilangkan item yang tidak memenuhi minimal support count, minimal support count yang digunakan adalah 2, berikut item yang dihilangkan karena memiliki nilai support count = 1 yaitu : 200, 2x1, 2x6, 100 . Selanjutnya di buat Conditional FP-Tree seperti pada tabel 2 dibawah ini : 
Tabel 2. Conditional FP-Tree untuk Path yang mengandung node $2 \times 3$

\begin{tabular}{|l|l|}
\hline Suffix & Conditional FP Tree \\
\hline $2 \times 3$ & $\{300,000,800: 1\}\{300,800: 1\}$ \\
\hline
\end{tabular}

Tahapan selanjutnya adalah pembentukan Frequently Pattern Growth, Frequently Pattern Growth di dapat dari penggabungan antara suffix pattern dengan Frequently Pattern yang dihasilkan dari Conditional FP-Tree. [4]

Tabel 3. Frequently itemset untuk node $2 \times 3$

\begin{tabular}{|l|l|}
\hline Suffix & Frequently Item Set \\
\hline $2 \times 3$ & $\{2 \times 3\}\{300,2 \times 3\}\{000: 2 \times 3\}\{800: 2 \times 3\}\{300,000,800,2 \times 3\}$ \\
& $\{300,800,2 \times 3\}$
\end{tabular}

Kemudian proses pembentukan Conditional Pattern Base, Conditional FP-Tree, dan Frequently item set berlanjut sampai semua prefix path yang berakhiran masing - masing item selesai di bentuk.

Tabel 4. Frequenlty Item set pada setiap item

\begin{tabular}{|c|c|}
\hline Item & Frequently Item Set \\
\hline $2 \times 7$ & $\{2 \times 7\}\{300,2 \times 7\}\{800: 2 \times 7\}\{300,800,2 \times 7\}$ \\
\hline $2 \times 3$ & $\{2 \times 3\}\{300,2 \times 3\}\{000: 2 \times 3\}\{800: 2 \times 3\}\{300,000,800,2 \times 3\}\{300,800,2 \times 3\}$ \\
\hline 900 & $\{900\}\{300,900\}\{100: 900\}$ \\
\hline $2 \times 1$ & $\begin{array}{l}\{2 \times 1\}\{300,2 \times 1\}\{000,2 \times 1\}\{200,2 \times 1\}\{800,2 \times 1\}\{300,000,200,800,2 \times 1\} \\
\{600,2 \times 1\}\{300,000,200,600,2 \times 1\}\{2 \times 0,2 \times 1\}\{300,2 \times 0,600,2 \times 1\}\{300,2 \times \\
0,600,800,2 \times 1\}\end{array}$ \\
\hline 800 & $\{800\}\{300,800\}\{000,800\}\{300,000,800\}$ \\
\hline 600 & $\{600\}\{300,600\}\{000,600\}\{300,000,600\}\{2 \times 0,600\}\{300,2 \times 0,600\}$ \\
\hline 200 & $\{200\}\{300,200\}\{000,200\}\{2 \times 6,200\}\{300,000,2 \times 6,200\}$ \\
\hline 100 & $\begin{array}{l}\{100\}\{300,100\}\{2 \times 0,100\}\{2 \times 6,100\}\{300,2 \times 0,2 \times 6,100\}\{300,2 \times 6,100\} \\
\{2 \times 0,2 \times 6,100\}\end{array}$ \\
\hline $2 \times 6$ & $\{2 \times 6\}\{300,2 \times 6\}\{2 \times 0,2 \times 6\}\{300,2 \times 0,2 \times 6\}$ \\
\hline $2 \times 0$ & $\{2 \times 0\}\{300,2 \times 0\}$ \\
\hline 000 & $\{000\}\{300,000\}$ \\
\hline
\end{tabular}

Selanjutnya adalah membuat association rules, association rules dihasilkan dari frequently item set. [4] sebagai contoh data yang mengandung frequent item $2 \times 7=$ $\{300,2 \times 7\}\{800,2 \times 7\}\{300,800,2 \times 7\}$,

association rule yang di dapat adalah dengan mensubsetkan semua item yang ber frequent pada item $2 \times 7$ :

$300=>2 \times 7 \quad$, confidence $=3 / 11=0,27$

$2 \times 7=>300 \quad$, confidence $=3 / 3=1$

$800 \Rightarrow 2 \times 7 \quad$, confidence $=2 / 4=0,5$

$300 \Rightarrow 800 \quad$, confidence $=4 / 11=0,36$

$800=>300 \quad$, confidence $=4 / 4=1$

$2 \times 7=>800 \quad$, confidence $=2 / 3=0,67$

$\{300,800\} \Rightarrow>2 \times 7$, confidence $=2 / 4=0,5$

$2 \times 7 \Rightarrow\{300,800\}$, confidence $=2 / 3=0,67$

$300 \Rightarrow>\{800,2 \times 7\}$, confidence $=2 / 11=0,18$

$\{800,2 \times 7\} \Rightarrow 300$, confidence $=2 / 2=1$

$800 \Rightarrow\{300,2 \times 7\}$, confidence $=2 / 4=0,5$

$\{300,2 \times 7\} \Rightarrow 800$, confidence $=2 / 3=0,6$

Jika minimum confidence yang digunakan adalah $80 \%$, maka rule yang di gunakan adalah $2 \times 7=>300,800=>300,\{800,2 \times 7\}=>300$.
5. Pengujian Perbandingan Rule yang dihasilkan terhadap nilai support dan confidence yang berbeda.

Pada tahapan ini data yang digunakan adalah data transaksi peminjaman buku pada tahun 2017, dan setelah melewati tahapan data selection, dan preprocessing menghasilkan tabel transaksi sebanyak 209 transaksi. Untuk pengolahan data alat bantu yang digunakan adalah rapidminer.

Tabel 5. Perbandingan Jumlah rule yang di dapat terhadap nilai support dan confidence yang berbeda.

\begin{tabular}{|l|l|l|l|l|l|l|l|l|l|}
\hline & 0.10 & 0.20 & 0.30 & 0.40 & 0.50 & 0.60 & 0.70 & 0.80 & 0.90 \\
\hline 0.10 & 198 & 124 & 58 & 36 & 24 & 14 & 8 & 3 & 2 \\
\hline 0.20 & 47 & 29 & 24 & 16 & 11 & 4 & 1 & 0 & 0 \\
\hline 0.30 & 22 & 13 & 11 & 10 & 8 & 4 & 1 & 0 & 0 \\
\hline 0.40 & 6 & 5 & 3 & 2 & 2 & 1 & 1 & 0 & 0 \\
\hline 0.50 & 0 & 0 & 0 & 0 & 0 & 0 & 0 & 0 & 0 \\
\hline
\end{tabular}

Dari Tabel 5 diatas di dapat semakin tinggi nilai minimum support dan confidence maka rule yang dihasilkan akan semakin berkurang serta semakin akurat untuk bisa di jadikan rekomendasi dalam pengambilan keputusan.

\section{SIMPULAN DAN SARAN}

\section{A. SIMPULAN}

Adapun kesimpulan yang di dapat dari hasil penelitian ini adalah :

1. Nilai minimum support dan confidence mempengaruhi jumlah rule yang dihasilkan semakin tinggi nilai tersebut maka rule yang dihasilkan akan semakin akurat.

2. Frequent Itemset di dapat apabila setiap item telah memenuhi minimum support count yang sudah di tentukan.

3. Rule yang dihasilkan dapat membantu pengambil keputusan dalam menentukan kebijakan selanjutnya.

4. Jika di lihat dari frekuensi jumlah kemunculan rule nilai support 0.10 dan confidence 0.50 atau nilai support 0,20 dan confidence 0.30 yang menghasilkan jumlah rule $=24$ rule bisa di jadikan rujukan dalam menentukan kebijakan. Diambil jumlah rule $=24$ di karenakan hampir semua itemset dari jenis buku dapat terbentuk pada rule tersebut.

\section{B. SARAN}

Adapun saran yang di dalam penelitian ini adalah :

1. Sebaiknya untuk implementasi algoritma FPGrowth ini di lanjutkan sampai ke penulisan code di dalam aplikasi pada sistem informasi perpustakaan.

2. Untuk mendapatkan hasil analisis yang lebih baik lagi, data yang diolah sebaiknya 
menggunakan seluruh transaksi peminjaman buku yang tersedia.

\section{DAFTAR PUSTAKA}

[1] Gregorius Satia Budhi, Andreas Handojo, Christine Oktavina Wirawan. 2009. Algoritma Generalized Sequential Pattern Untuk Menggali Data Sekuensial Sirkulasi Buku Pada Perpustakaan UK PETRA. Yogyakarta : Seminar Nasional Aplikasi Teknologi Informasi.
[2] Ririanti. 2014. Implementasi Algoritma FP-GROWTH Pada Aplikasi Prediksi Persediaan Sepeda Motor (Studi KasusPT.PILAR DELI LABUMAS)

[3] Kusrini, Lutfi, Emha Taufiq. 2009. Algoritma Data Mining. Andi:Yogyakarta.

[4] Jiawei Han, Micheline Kamber, Jian Pei. 2012. Data Mining Concept and Techniques Third Edition.

[5] Sugiyono.2009. Metode Penelitian Kuantitatif, Kualitatif dan R\&D. Bandung : Alfabeta. 